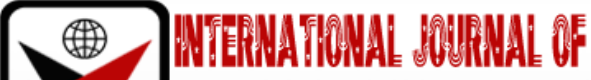 \\ בmas
}

ISSN 2278-0211 (Online)

\section{Corporate Governance and Environmental Policy Index of Sustainability Reporting in Oil \& Gas Companies Quoted in Nigeria}

\begin{tabular}{|c|}
\hline Arogundade Jamiu Adewale \\
Doctoral Student, Department of Accounting, \\
Babcock University,Nigeria \\
Sunday Ajao Owolabi \\
Professor, Department of Accounting, \\
Babcock University,Nigeria \\
Folajimi Festus Adegbie \\
Professor, Department of Accounting, \\
Babcock University Ilishan Remo, Ogun State, Nigeria
\end{tabular}

\begin{abstract}
:
Evidently, environmental sustainability reporting was faced with unprecedented challenges due to environmental degradation, inadequate handling of environmental protection by polluting-intensive companies' selective disclosure approach predominantly in the oil and gas companies in Nigeria. This work aimed at examining the effect of corporate governance on environmental policy index of sustainability reporting in oil and gas companies quoted in Nigeria. Expost-facto research design was adopted and the population of the study comprised all the 12 oil and gas companies quoted in Nigeria as at 31 ${ }^{\text {st }}$ December 2020, from which a sample of 8 companies was formulated. Data were extracted between 2006 and 2020 from published financial statements of the sampled companies and environmental disclosure checklist in line with Global Reporting Initiatives. Multiple regression was used in analyzing the data. The study revealed that environmental sustainability reporting of oil and gas companies quoted in Nigeria was significantly affected by corporate governance, $\left(\right.$ Adj $R^{2}=0.157 ;$ Wald-test $=21.18 ; P$-value $\left.=0.000\right)$. Also, firm size and firm leverage significantly controlled the effect of corporate governance on environmental policy, $\left(A d j R^{2}=0.180\right.$; Wald test $=32053$; $P$-value $=0.000$ ). It was concluded that, there is significant positive effect of corporate governance on environmental policy index of sustainability reporting in oil and gas companies quoted in Nigeria and also, corporate governance with moderating effect of firm size and firm leverage had positive significant effect on the environmental policy index of sustainability reporting in oil and gas companies quoted in Nigeria. The study recommended that Shareholders should obtain adequate information on environmental protection before taking investment decisions, planning and portfolio diversifications in the oil and gas companies in Nigeria.
\end{abstract}

Keywords:Corporate governance, Environmental sustainability reporting, Firm size, Oil and gas, Quoted companies

\section{Introduction}

The events of oil and gas crises and unstable global oil prices had placed oil and gas companies in the gaze of public opinion and investors more than before, have reacted, intensifying efforts in prompting oil and gas to ensure more transparent reporting of environmental protection and issues relating to sustainability reporting in the oil and gas industry, with the aim of counteracting the negatives effects of the past loss of reputation following noncompliance to environmental reporting (Budiharta\&Kacaribu, 2020). While the oil and gas companies were under severe pressure and obligated to a sufficient return to equity holders, the companies were equally under the burden to environmentally responsibility demands of a transparent and sustainable reporting of its environment performance to the public and to other stakeholders (Nasir, Kashan, Maleki, Jafari\&Hashemi, 2020; Sabishchenko, Rebilas, Sczygiol\&Urbanski, 2020).

Environmental accounting reporting serves as means through which environmental sensitive corporations bring to the knowledge of its investors and other stakeholders their environmental protection performance towards improving and adding values, safeguard corporate reputation and image as well as creating a sustainable base for enhanced earnings and future returns and ability in meeting these demands were quite complex and multitasking (Cardoni, Evgeniia\&Terzani, 2019; Yang \& Yan, 2020). The global community especially in the developing economies had suffered the deepened and unpleasant consequences of neglects of the environmental degradations and setbacks in environmental sustainability reporting in the oil and gas industry and among environmental sensitive organizations (He, Shen, Zhang \& Ren, 2019; Hussain, Slusarczyk, Kamarudin, Thaker\&Szxzepa, 2020). The studies from the advanced and developing countries seemed 
inconsistent, yet reflect on the level of desertions and deprivations of the environment; unfortunately, this seemed predominantly disturbing in the developing economies (Cupertino, Consolandi\& Vercelli, 2019; Grigorescu, Maer-Matei, Mocanu\&Zamfir, 2020; Owolabi, Adegbie \& Oyetunji, 2020).

The problems affecting environmental sustainability reporting have been extensively analyzed to an impressive level in Australia, Canada, United Kingdom and other European countries (Perrault \& Clark 2016). In Europe, the studies of Nosratabadi, Pinter, Mosavi and Semperger (2020); Saona, Muro, Martin, Baier-Fuentes (2019) documented that there was a growing concern and increasing demand on corporate organizations to performs on conscientiously on social responsibilities encompassing environmental policies, respect to juridical legal framework of compliance with standards and laws, and ethical and cultural beliefs of the society. According to Mahmood, Kouser, Ali and Ahmad (2018), corporate sustainability reporting was another global concern, as a growing number of scholars have argued that corporate organizations operational activities have huge impact on the external environment, and that was why these companies should be held responsible and accountable to shareholders and to a wider audience than simply its shareholders alone.

Haladu (2016) and Hu, Du and Zhang (2020) documented that, the highest enemy and threat to the environment was the acceptance or belief that someone else will save and protect the environment, as the protection and preservation of the environment was everybody and every organization collective responsibility. Efale and Otuya (2018) posited that environmental policy was essentially required to remind and guide corporate organization as one of its strategic policies to ensure environmental sustainability reporting. On collaboration and consistent with Efale and Otuya (2018), Ouvrard, Jasimudin and Spiga (2020) stressed that corporate governance was capable of influencing environmental policies by its corporate strategic decisions and the amount of investments and related annual budgeted overheads policy to finance environmental protection.

Edike and Otuya (2018) submitted that over consumption of paper at home or at office places has huge negative environmental consequences and discarded waste papers equally contribute solid wasted which eventually block drainages and landfill and therefore environmental policy have the potency to guide the management and the board exercising it oversight and monitoring functions. However, on the contrary, Benneth, Schaltergger and Zvesdov (2017); as well as Munteanu, Grigorescu, Condrea and Pelinescu (2020) argued that corporate governance was not interested, committed and do not prioritize environmental policies in its strategic decisions. According to Sulkwowski, Edward and Freeman (2017), the firm size was a factor, as bigger companies guide corporate image and ensure that environmental policies were viewed serious, however, Gul, Mohammad and Rashid (2017) argued that firm size and capital capacity of firm have not affect corporations making efforts to protect the environment. Consequent on these divergent positions and opinions, this study was motivated to investigate empirically, the effect of corporate governance on environmental policy index of sustainability reporting in oil \& gas companies quoted in Nigeria.

\subsection{Objectives of the Study}

The objectives of this study are to:

- $\quad$ investigate the effect of corporate governance on environmental policy index of sustainability reporting in oil and gas companies quoted in Nigeria;

- investigate the moderating effect of firm size and firm leverage on the effect of corporate governance on environmental policy index of sustainability reporting in oil and companies quoted in Nigeria;

\subsection{Research Hypotheses}

- $\mathrm{H}_{01}$ : Corporate governance has no significant effect on environmental policy index of sustainability reporting in oil and gas companies quoted in Nigeria.

- $\mathrm{H}_{02}$ : There is no significant moderating effect of firm size and leverage on the effect of corporate governance on environmental policy index of sustainability reporting in oil and gas companies quoted in Nigeria.

\section{Literature Review}

Ong, Tho, Goh, Thai and Teh (2016) defined environmental policy index the various checklist of environmental procedures and course of action stipulated to regulate environmental protection, goals and sustainability roadmap. It was imperative that corporate bodies abide by international and local jurisdiction legal and regulatory framework to enhance environmental protection and transparency reporting (Alhassan\&Mansor, 2019). Environmental policy index comprises of full and timely disclosure of information relating to present and potential cases that could result to litigations, and contingent liabilities Akbas (2016), current and probable fines, waste management and disposal policies information put in place by the concerned il and gas companies, and level of compliance by the staff and management of the oil and gas policy measure to guide against or reduction of noise pollution and emission information (Ezeagba, John-Akamelu \& Umeoduagu, 2017). Environmental policy index also includes environmental target and management of environmental policy statements, oil and gas Companies concern for the environmental issues and evidence of actions being implemented in all-inclusive environmental related information (Oti\&Mbu-Ogar, 2018).

There were diverse environmental policy concerns related to oil and gas Companies in Nigeria, and some of these concerns were the issues of the use and potential misuse of water and possible absence of water conservations and waste paper disposals. Oil and gas Companies with its various branches require paper for its stationery; require a continuous water, diesel and noise of the heavy duty generators. More so, a regular and constant water supply was required for toiletries and high level of water use may possibly lead to volumes of wastewater and could require policy of usage and consistent toilet flushing and washing of hands (Oncioiu, Petrescu, Bilcan, Petrescu, Delia-Mioara, Anghel, 2020). The issue of environmental protection and preservation require oil and gas companies to have a working all-encompassing 
environmental policy and measures put in place to ensure its strict compliance, that of the corporate body and that of the local authorities put in place to protect the environment and evidence of such protection.

Beyond this, the other environmental risk and concern that required environmental policy was the energy consumption. The oil and gas companies and its widely spread branches consume huge amount of energy in heat and power generation. The sector cannot function with a consistent and continuous energy for lighting, powering the air conditioning, the computers and Automatic Teller Machines (ATM). Apparently, this huge energy consumption puts high pressure on overstretched local electricity supplies, resulting to heavy duty generators with its consequential negative effects on the environment such as noise pollution from the heavy duty generators, emission of smokes (Mulyanto, Awatara\&Gunardi, 2018). For this reason, the oil and gas companies must have an environmental policy to regulated and improve energy efficiency and conservation such as use of renewable energy and consideration.

\subsection{Theoretical Framework}

The study was underpinned on signaling theory and agency theory based on the literature reviewed and considerations through the main variables that formed the research questions and hypotheses. While signaling theory was to reinforce the dependent variable of environmental sustainability reporting, the agency theory was expected to support the independent variable of the study, corporate governance. In addition, signaling theory was chosen as the underpinning theory for environmental sustainability reporting because a signal or disclosure of environmental information has a good news and value implication to the entity while bad news of noncompliance to environmental policies could negatively effect on the fortunes of the company. Environmental sustainability reporting and its consistent compliance was another meant of communicating the shareholders and other stakeholders expected information they expect to know. Theoretically, the signaling theory was concerned with information disclosure behavior of managers in the presentation of their corporate sustainability reports and the likely reactions of the shareholders, and other interested groups whenever there was a new announcement of new information, whether good news or bad news. Therefore, this study proposes that Signaling theory will be suitable as one of the underpinning theories for the study.

Furthermore, agency theory was selected as the bed rock upon which the independent variable of corporate governance hangs because of the relationship between the principal (shareholders) and the agents (managers) to ensure that some inherent conflict of interest in the relationship was adequately controlled. Corporate governance was expected to ensure that the interest of the managers and shareholders including the stakeholders were properly protected and that the environment was fairly protected as well. More so, the corporate governance was concerned with international best practices in handling and resolving the complexities of contractual obligation of the principal-agents relationship. The principal (shareholders) expect wealth maximization while the managers (agents) have the incentive to pursue the shareholders wealth maximization, managers were equally motivated to carry out shareholders bid because of their own interest. Theoretically, the agency theory was relevant and appropriate to be chosen as one the underpinning theory of the study. Other theories chosen and reviews because of their relevance to the study include: stakeholder theory, stewardship theory, resource dependence theory, behavioural finance theory and lending credibility theory.

\subsection{Corporate Governance and Environmental Sustainability Reporting}

In a study that involves sustainability practice and reporting among environmental sensitive companies in Nigeria, Oyewo and Badejo (2014), undertook an empirical examination to examine the sustainability development reporting practices among the listed oil and gas companies in Nigeria. The study employed a 30-item checklist construct for a content analysis for a period of one year 2012 using published annual oil and gas statements of the selected listed oil and gas companies for sustainability practice disclosures. The sustainability were group in three of social, economic, environment and then general. The study employed correlation analysis in analyzing the relationship among the variables. The study result found that the oil and gas companies in Nigeria engaged more in the social aspect of sustainability. Also that there was no significant (negative) relationship in sustainability practices among the firms, while firm attributes of firm size and profitability had no effect on sustainability practice among the oil and gas companies selected for the study in Nigeria. The result obtained in the study of Oyewo and Badejo (2014) was found to be consistent with the result obtained in the study of Amarjit and Obradovich (2015) however the result found by Oyewo and Badejo was inconsistent with the study of (Weng, Chen \& Chen, 2015).

Onyali, Okafor and Onodi (2015) evaluated the rate of effectiveness of triple bottom line disclosure of environmental sustainability practice among the corporations from the stakeholders' perspective in Nigeria. The study descriptive with a population of three different groups of stakeholders of: Accountants, investors and customers/consumers. The study employed data obtained from primary source of questionnaires. The study found that the three was a negative effect of the triple bottom line with investors and consumers in disclosure practice among the companies sampled in Nigeria. Curiously, two studies in Nigerian, found different results, one found positive effect and the other found negative effect, a closer look revealed that while Oyewo and Badejo (2014) undertook an empirical examination to examine the sustainability development reporting practices among the listed oil and gas Companies in Nigeria, Onyali, Okafor and Onodi (2015) was not specific on the sector studied. While Oyewo and Badejo (2014) adopted secondary data, Onyaliet al., (2015) employed primary data, making the two studies revealed mixed results. Further investigation may likely validate one of the studies.

Obeitoh, Ridzwana and Zaidi (2017) investigated the determining factors and level of disclosure compliance of corporate sustainability on employees in the economy of Malaysia. The study stretched for a period of 6 years 2010-2015, using 253 companies in Malaysia. The study also explored the use of two-step system generalized methods of moments for the data analysis. The study found that firm size had a positive relationship with the compliance of corporate sustainability 
information disclosure among the sampled companies in Malaysia. The result obtained in this study of ObeitohRidzwana and Zaidi (2017) result was consistent with previous studies that have shown that big sized firms may have first mover advantages based on investments in adequate funding thereby giving them better opportunities to invest in viable portfolio companies ahead of small sized companies (Eneh\&Amakor, 2019; Adeneye\& Ahmed, 2015). However, Odoemelam and Okafor (2018) posited that large sized companies most often invested excess capital which often created agency challenges thereby destroying value based on conflict between the agent and the principal. These studies still confirm that firm size had effect on the ability of companies to respond to environmental sustainability reporting, as big sized firms were interested in protecting their image and would not risk not complying with environmental sustainability reporting.

Egbunike and Tarilaye (2017) investigated the association the existing between firm specific attributes among listed manufacturing companies in Nigeria. The study sort to establish the level of voluntary and mandatory environmental disclosure and leverage level among the manufacturing companies that were expected to comply with environmental information disclosure in Nigeria. The study covered a period of 6 years 2011-2015, using data obtained from published annual oil and gas statement of the sampled companies. The result of the study revealed that the companies investigated were highly geared profiles and the level of disclosure were not ascertained.

Gholami, Sulaiman, Ramayah and Molla (2013) investigated the effects of managers' perception of information systems and analysis on environmental performance. The study applied a theoretical foundation of belief-action-outcome model to capture the effects of green system adoption by establishments on environment performance enhancements. The study found that coercive pressure exercise had a positive effect on green information system and that information system analysis had a weak positive significant on environmental performance. Furthermore, the study was unable to confirm the contribution of mimetic pressure in influencing information system adoption. While the study of Egbunike and Tarilaye (2017) who investigated the association existing between firm specific attributes and environmental reporting among listed manufacturing companies in Nigeria found that the level of environmental sustainability reporting compliance was uncertain, but Gholami, Sulaiman, Ramayah and Molla (2013) found a contrary result, revealing that coercive pressure exercise on the board and the management team had a positive effect on environmental reporting compliance a weak positive significant on environmental performance.

Henri and Journeault (2010) investigated the effect and role of monetary strategic controls on of environmental enhancement and economic performance. The study adopted qualitative method in carrying out the investigation. The study found out that eco-control had a positive insignificant effect on environmental performance. Furthermore, the study revealed that there was a positive significant relationship between eco-control and economic performance. The study concluded that environmental performance mediates an effect of eco-control on economic performance among the Canadian manufacturing companies. This study was consistent with previous studies that had found positive effect of corporate governance on environment sustainability, this findings was important because of eco-control here was quite compassing, including all the variables considered for environmental sustainable reporting in this study. While the study of Henri and Journeault (2010) carried out in Canada was found to be consistent with the study of Xing, Liu, Wang and Zhu (2019) carried out in China, the study was found to be inconsistent with the result obtained in the study of Akinwunmi, Owolabi and Akintoye (2018), who found that ethnicity as one of the measures of corporate governance exhibited a negative relationship with Tobin's Q. Furthermore, that board religious diversity had a negative and insignificantly related to return on assets and on Tobin's $Q$.

Akbas (2014) investigated the association that do exist between for firm characteristics and environmental disclosure of companies listed on BorsaInstanbul 100 Index data-base in Turkey. The study employed 62 non-oil and gas companies for a period of one year 2011. The study used leverage as a firm characteristics and the study found that leverage had no statistical significant relationship with the extent of environmental disclosure. In the same manner, AgyeiMensah (2016) studied Ghanaian economy by investigating the effect of firm-specific characteristics of debt equity ratio on voluntary disclosure level of rural firms in the Ashanti region of Ghana. The study result found that debt equity ratio was insignificantly related to the disclosure level among the firms sampled in the study. Both studies of Akbas (2014) and that of Agyei-Mensah (2016) revealed similar results, as such were consistent, but the studies result were inconsistent with the result obtained by Asuquo, Dada and Onyeogaziri (2018), who found that corporate governance induced oil and gas disclosures had a critical and positive influence on return on asset of the listed and sample companies in Nigeria.

Umukoro, Uwuigbe, Uwuigbe, Adegboye, Ajetunmobi and Nwaze (2019) studied the impact of environmentally sensitive, certified or educated board member and/or board expertise on sustainability reporting in listed environmental sensitive firms in Nigeria. The study covered a period of 3 years of 2014 to 2016, using 10 selected oil and gas in Nigeria. The study found that highly educated directors had constructive impact on the sustainability report disclosure while controlling for corporate administration and firm-level qualities. The study also found that executive and non-executive directors had low experience in environmental issues resulting in insignificant effect on the disclosure of sustainability reporting. The study recommended that firms especially the listed firms should allow more directors with environmental experience and background as they were likely to influence environmental reporting performance. Umukoroet al., 2019) was found to have a similar result with the result obtained in the study of Otuya, Akporien\&Ofeimun, 2019), however inconsistent with that of Nwaiwu and Oluka (2018). Apparently, the finding was instructive that experience and education of the board members were important, beyond the education and experience, competence and efficient board were significant in making instill environmental sustainability protection and reporting culture by every corporate organization and the oil and gas sectors in particular who think that environment protection was that of the manufacturing companies only. 
Ameer and Othman (2012) studied the effect of sustainability on corporate oil and gas performance of some top global corporations within the developing countries. The study employed a bi-directional methodology, using 4 identified sustainability indexes of diversity, environment, ethics and community as measures of sustainability while return on assets was used to proxy corporate oil and gas performance for a period of 5 years 2006-2010. The study found that there was a positive relationship between sustainability and corporate performance practices. This was consistent with the studies of Osemene, Kolawole and Oyelaun (2016; Burhan and Rahmanti (2012) but not consistent with the result obtained in the study of Adediran and Alade (2013).

Adeneye and Ahmed (2015) investigated the effects of corporate social responsibility on company performance, measuring company performance using firm size return on capital employed. The study utilized 500 UK firm. The study found that there was a positive statistical relationship between firm size, return on capital employed and corporate social responsibility among the 500 companies in UK sampled for the study. The study and result found by Adeneye and Ahmed (2015) was consistent with some previous studies (Odoemelam and Okafor (2019); Laskar, Chakraborty and Maji (2017), not found to be inconsistent with the result obtained by Butt (2019) who revealed that environmental reporting, and leverage had a negative association with corporate governance signifying a subset of management inefficiencies.

Asuquo, Dada and Onyeogaziri (2018) examined the performance of economic disclosure of some selected listed corporations in Nigeria, the study measured performance with return on assets. The study revealed that the corporate governance induced oil and gas disclosures had a critical and positive influence on return on asset of the listed and sample companies in Nigeria. Both studies of Adeneye and Ahmaed (2015) and that of Asuquo, Dada and Onyeogaziri (2018) were confirming the effects of corporate government on information disclosure which include that of environmental sustainability of oil and gas reporting, except that considered moderating variables of firm size not employed in the study of Asuquoet al., (2018).

Meca and Palacio (2018) investigated the effect of board composition on firm reputation from the perspective of business experts, support specialists and community influential. The study grouped board members into different business specialist, bolster pros, political directors and other network international conference on energy and sustainability persuasive. The essence was to explore business specialized ability or political tiers in the meet influences decisions in the board. The study found that outside directors, independent directors and business specialists had positive and compelling effect on decisions of the board during board meetings. Meca and Palacio (20180 found similar result with that of the studies of Nwobu (2015) and the result obtained by Susanto and Meiryani (2019), who found that structural equation modelling confirm that environmental accounting information system, and environmental accounting information capability had a positive and significant impact on firm performance.

Sanusi and Sanusi (2019) studied the popularity and level of compliance to the practice of environmental sustainability reporting in some quoted manufacturing companies in Nigeria. The study sort to examine the effect of environmental sustainability practices on the oil and gas reporting in improving oil and gas performances of the manufacturing companies in Nigeria. The study employed environmental sustainability indexes and measured oil and gas performance using earnings per share, revenue growth and return on assets. A survey research design was used covering a period of 6 years 2010-2015. Descriptive and inferential statistics were used in the analysis of the study. The study found that majority of the manufacturing companies were familiar with environmental sustainability reporting practice, but the compliance rate was low. The study equally found that the compliance had weak and positive significant influence on the oil and gas performance of the manufacturing companies. The study recommended that at annual general meetings, shareholders should mandate the board and the management of their companies to have a well-structured policies to adhere and comply with environment sustainability reporting and practices. The study of Sanusi and Sanusi (2019) was similar to the result obtained by Henri and Jourmeault (2010) who found out that eco-control had a positive insignificant effect on environmental performance. Furthermore, the study revealed that there was a positive significant relationship between eco-control and economic performance. Bu the result was an inverse with the one found in the study of (Otuya, Akporiem\&Ofeimun, 2019).

Ehimare, Taiwo and Okorie (2013) investigated the roles of corporate governance in the growth of firms and a critical review of some cases of abuse of trust by the board of directors of the firms in Nigeria. The study employed multiple regression analysis, using ordinary least square and the statistical significance of the data was validated using ANOVA statistics in analyzing the data obtained from the firms sampled for the study. The study found that there were some observed problems of the firm's corporate governance: instability of board tenures, constant squabbles in the board, ownership crisis, and high level of inside dealings. The weaknesses were found included ineffective board oversight function, disagreement between boards and management results to squabbles, lack of experience among the board members, and weak internal control. The study advised that poor corporate governance's issues be handled carefully while customers should make observed cases to the oil and gas regulatory bodies in Nigeria.

Juan (2020) carried out a critical and systematic review of sustainability oil and gas through a co-word analysis. The study was carried out using qualitative methods and content analysis based on observed gaps in some oil and gas sectors poor responses on sustainability practices and reporting. The study review revealed that a rapid evolution of the sustainability practice and reporting were negatively related with performance of the firms and were inadequate and the consequences of oil and gas sustainability program on the competitiveness were eminently unavoidable. The study recommended that complexities of the sustainability models were glaring, as such, the future stakeholders be considered. The result found in the study of Juan (2020) was similar to an earlier result obtained in the study of Onyali, Okafor and Onodi (2015), but dissimilar to the one found by the study of Marimuthu (2008), who found that ethnic diversity on the companies' boards of directors had a positive significant effect on firm oil and gas performance in the selected and sampled companies in Malaysia for the period covered by the study. 
Nwobu (2015) examined the effects of corporate sustainability on profitability and shareholders fund in Nigeria. Annual oil and gas statements of firms in Nigeria with the aim of establishing the level of sustainability reporting in line with the Central Bank of Nigeria reporting guideline for oil and gas sectors. The study selected 8 listed oil and gas companies with tan attempt to build on determinants of corporate sustainability reporting using accounting based measures of organizational performance. The study adopted variant content analysis methodology, using disclosure index. Profit after tax and shareholders fund were proxies adopted for the profitability and shareholders' fund, data for the study were extracted from the published annual oil and gas statements of the 8 sampled firms. The result revealed that the firms had complied substantial on sustainability reporting for the past 4 years. The study also found that there was a weak relationship between sustainability reporting index and profit after tax and a weak positive relationship between sustainability reporting index and shareholders' fund. The study then stated that there was strong evidence that sustainability reporting in the Nigerian oil and gas industry was gradually gaining attention, since this was necessary to enable the Central Bank of Nigeria to evaluate the responses rate of the firms in sustainability reporting regulatory guidelines in Nigeria.

The studies of Nwobu (2015) and that of (Meca and Palacio (2018); Sanusi and Sanusi (2019); Ehimare, Taiwo and Okorie (2013) had close similarities, however, While Meca and Palacio (2018)'study revealed that outside directors, independent directors and business experts in the board jointly had a statistically positive effect on environmental sustainability reporting, that of Sanusi and Sanusi (2019) had shown that there was a weak compliance of environmental sustainability reporting among the manufacturing companies in Nigeria and this had a weak influence on the oil and gas performance of the companies. Consistent with Sanusi and Sanusi (2019) was the study of Ehimareet al., (2013) that revealed a weak internal control and inexperience board member as a reflection of inefficient corporate governance among the companies investigated.

Manning, Braam and Reimsbach (2018) examined the effects of board monitoring effectiveness and stakeholders' engagement on corporate sustainability performance and disclosure choices. The study sampled some selected Dutch companies that have voluntary disclosure sustainability reporting during a period of 5 years (2012-2016). The study distinguished between non-lagged and lag effects, by adopting a structural equation modeling to also investigate the potential indirect effect of the corporate governance on sustainability reporting quality and sustainability reporting standards via corporate sustainability performance in Dutch companies. The study found that in the short run, the companies monitoring effectiveness had a positive significant effect on sustainability reporting quality and sustainability reporting standards. Also that stakeholder's engagement had a positive effect on sustainability reporting quality and sustainability reporting standards both in the short and long run periods. This implies that active stakeholders over time, could drive companies toward more responsive sustainability business conduct consciousness. In addition, the result corporate sustainability performance exhibited a positive effect on sustainability reporting quality but negatively associated to sustainability reporting standards. The result found in the study of Manning, Braam and Reimsbach (2018) was consistent with the result found in the study of Saman (2019), however was found to be inconsistent with the result of Birindelli, Dell-Atti and Iannuzzi (2018).

Laskar, Chakraborty and Maji (2017) examined the effects of corporate sustainability practices and performance on oil and gas performance of companies in Asian context considering companies Japan and India. The data were obtained a secondary data collected from annual reports and corporate sustainability report of 28 companies in Japan and 38 listed companies in India, covering a period of 6 years 2009-2014. The study adopted content analysis (binary coding system) to calculate sustainability disclosure index scores based on Global Reporting Initiative framework, while market to book ratio was employed to measure oil and gas performance. The obtained scores were also used in examining the effect of corporate sustainability performance on oil and gas performance in both the panel and logit regression models. The study found that the corporate governance had a weak positive effect on oil and gas performance of companies in Asia countries of Japan and India and also an average level of disclosure was more impressive in Japanese companies as compared to India. Also the study found that the corporate sustainability had a positive significant effect on performance oil and gas performance, that the effect was stronger in Japan when compared with that of India. Finally, the study showed that while the effect of environment was more in Japan, it was the social factors that dominated the oil and gas performance in India. This result found by Nwaiwu and Oluka (2018) but inconsistent with the result obtained in the study of Ezeagba, John-Akamelu and Umeoduagu (2017). In line with the variable for our study, this section results have shown that effect of corporate governance has been vastly considered to have both positive and negative effect on the environmental sustainability reporting especially in companies sensitive to environmental pollutions, air pollution, waste disposals, from various sectors both from advanced economies and from Nigeria. However, few of these studies had concentrated on oil and gas sectors.

\section{Methodology}

The study adopted expostfacto research design with population comprised of the twelve (12) firms from the oil and gas sectors listed on the Nigeria Stock Exchange market as at 31/12/2020. With the aid of judgemental sampling technique, eight companies were selected. Data was collected through the secondary source, environmental indicators as per Global Reporting Initiative (GRI) check list was obtained from secondary sources for a period of fifteen (15) years (2006-2020), as well as the audited oil and gas financial statements of the selected environmentally sensitive oil and gas companies listed on the Nigeria Stock Exchange.The extent of environmental sustainability reporting was determined by conducting a content analysis of the annual reports of the eight (8) listed oil and gas environmentally sensitive firms that were selected for this study for the period of fifteen (15) years (2006-2020). Each annual report was carefully checked and scored in order to construct a disclosure index based on items researcher-developed checklistconsisting of 21 items. 
The environmental disclosure score was a simplified version of GRI environmental reporting and it was computed as the average value of the dummy variables from materials disclosures, energy disclosures, water, biodiversity, emission, effluents and water, product and services environmental impact and compliance to law regulation disclosures. Validity was predicated on statutory auditing and certification by external auditors. Panel data regression approach which involved the use of Random or Fixed Effect estimators was employed as it allowed the researcher to combine both the time series and cross-sectional data as used in previous studies of (Ghani, Jamal, Puspitasari\&Gunardi, 2018; Kilic\&Kuzey, 2017).

\subsection{Functional Relationship}

The functional relationship in the study is as shown below:

$Y=$ Environmental Policy Index (ENVPY),

$X=(B D S Z E$, BDINDP, WMBD, FRBDM, INSH)

BDSZE $=$ Board Size

BDINDP = Proportion of Board Independent,

WMBD = Women on Board,

FRBDM = Frequency of Board Meeting,

INSH= Institutional Holding

$Z$ = Moderating Variables (Firm Size (FSIZ), Firm Leverage (FLEV)

Therefore, the model was explicitly specified as:

\subsection{Specific Models}

Model 1

Model 2

$$
E N V P Y_{i t}=\alpha+\beta_{1} \text { BDSZE }_{i t}+\beta_{2} \text { BDINDP }_{i t}+\beta_{3} \text { WMBD }_{i t}+\beta_{4} \text { FRBDM }_{i t}+\beta_{5} \text { INSH }_{i t}+\varepsilon_{i t}
$$

$$
\begin{aligned}
& E N V P Y_{i t}=\alpha+\beta_{1} \text { BDSZE }_{i t}+\beta_{2} \text { BDINDP }_{i t}+\beta_{3} \text { WOMOD }_{i t}+\beta_{4} \text { FRBDM }_{i t}+\beta_{5} \text { INSH }_{i t}+\beta_{6} \text { FSIZ }_{i t}+\beta_{7} \text { FLEV }_{i t} \\
& +\varepsilon_{i t}
\end{aligned}
$$

\section{Results and Discussion of Findings}

\subsection{Test of Hypotheses}

\subsubsection{Hypothesis One}

- Research Objective One: investigate the effect of corporate governance on environmental policy index of sustainability reporting in oil and gas companies quoted in Nigeria;

- Research Question One: How does corporate governance affect environmental policy index of sustainability reporting in oil and gas companies quoted in Nigeria?

- Research Hypothesis One $\left(\mathrm{H}_{01}\right)$ : Corporate governance has no significant effect on environmental policy index of sustainability reporting in oil and gas companies quoted in Nigeria.

\begin{tabular}{|c|c|c|c|c|}
\hline Variables & Coefficient & Cluster Standard Error & t-test & Prob. \\
\hline Constant & -0.049 & 0.318 & -0.154 & 0.882 \\
\hline BDINDP & -0.073 & 0.232 & -0.313 & 0.763 \\
\hline BDSIZE & $0.401^{* *}$ & 0.143 & 0.212 & 0.838 \\
\hline WMBD & 0.077 & 0.361 & 3.041 & 0.332 \\
\hline FRBDM & 0.610 & 0.586 & 0.247 & 0.017 \\
\hline INSH & $0.766^{* *}$ & & & \\
\hline Adjusted R & 0.097 & & & \\
\hline F-Test & $9.01(0.006)$ & & & \\
\hline Hausman Test & $12.74(0.026)$ & & & \\
\hline Testparm & $11.19(0.000)$ & & & \\
\hline Heteroscedasticity Test & $1240.78(0.000)$ & & & \\
\hline
\end{tabular}

Table 1: Corporate Governance on Environmental Policy Index of Sustainability Reporting

Dependent Variable: ENVPY

Source: Researcher's computation (2021) 
- $\quad$ Notes: Table 1 reports the cluster fixed effect model that corrects for autocorrelation and heteroscedasticitypanel regression results of the effects of corporate governance on environmental policy index of sustainability reporting of selected oil and gas companies Nigeria. The dependent variable was Environmental Policy Index of Sustainability Reporting (ENVPY). The independent variables were Board Independence (BDINDP), Board Size (BDSIZ), Institutional Holding (INSH), Women on Board (WMBD), and Frequency of Board Meeting (FRBDM).

- $\quad$ Significant at $10 \%,{ }^{* *}$ Significant at $5 \%,{ }^{* * *}$ Significant at $1 \%$.

\subsubsection{Interpretation of Diagnostic Test}

From Table 4.1, the diagnostic test reported were the Hausman test, the Testparm for fixed effect test, the heteroskedasticity, the Wooldridge test for autocorrelation and the Pesaran's test of cross-sectional independence, these tests were carried out so as to determine the appropriateness of the estimation technique for the specified model. First, the Hausman test was used to determine the appropriateness between the fixed effect and the random effect model. The null hypothesis of the Hausman specification test was that there was no correlation between the random effect and fixed effect model, thus the random effect estimates were efficient and consistent, and that the fixed effect estimates were inefficient and the alternative hypothesis that the fixed effect model was consistent and efficient. The Hausman statistic of 12.74 with a probability value of 0.026 was less than the $5 \%$ level of significance hence, the rejection of the null hypothesis and the acceptance of the alternative hypothesis. This implies that the fixed effect model was efficient and appropriate. To determine the appropriateness of the fixed effect model, the testparm for fixed effect test was conducted; the result showed that the statistic of 11.19 with a probability value of 0.000 was less than the $5 \%$ level of significance. Thus, the fixed effect model was appropriate.

To determine the cross-sectional dependence between the selected oil and gas companies in Nigeria, the Pesaran CD test was used. The statistic of -1.667 and with a probability value of 0.095 was not was statistically significant at $5 \%$ level of significance. This implies that the selected oil and gas companies were cross sectional independence. The BreuschPagan/Cook-Weisberg test for heteroscedasticity was carried out to determine if the variance of the residual was constant. The null hypothesis of homoscedasticity was rejected and the alternative hypothesis of heteroscedasticity was accepted. This was because the test statistic of 1240.78 was statistically significant at 1 per cent level.

In testing for autocorrelation in the panel data, the Wooldridge test was used. The null hypothesis that the successive error terms were not correlated was rejected in favour of the alternative hypothesis that the successive error terms were serial correlated because the statistic of 271.66 with a probability value of 0.000 which was less than the $5 \%$ level of significance. However, with the presence of autocorrelation and heteroscedasticity, the study used the cluster option for the fixed effect model.

Model 1:

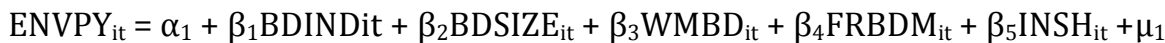

ENVPY $_{i t}=-0.049-0.073 B D I N D i t+0.401$ BDSIZE $_{i t}+0.077 \mathrm{WMBD}_{\mathrm{it}}+0.610 \mathrm{FRBDM}_{\mathrm{it}}+0.766 \mathrm{INSH}_{\mathrm{it}}$

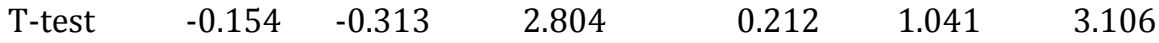

\subsubsection{Interpretation of Results}

Table 1showed the results of regression analysis of the effects of corporate governance on environmental policy index of sustainability reporting of oil and gas companies in Nigeria. The results show that board size, women on the board, frequency of board meetings, and institutional holding have positive relationship with environmental policy index of sustainability reporting of oil and gas companies in Nigeria, while board independence has a negative relationship with environmental policy index of sustainability reporting of oil and gas companies in Nigeria.

In addition, there was evidence that board size and institutional holding have significant relationship with the environmental policy index of sustainability reporting of oil and gas companies in Nigeria (BDSIZE $=0.401, \mathrm{t}$-test $=2.804$, $\mathrm{p}$ $<0.05$ and $\mathrm{INSH}=0.766$, t-test=3.098, $\mathrm{p}<0.05$ ) respectively. This implies that board size and institutional holding were significant factors influencing changes in the environmental policy index of sustainability reporting of oil and gas companies in Nigeria.

Conversely, there was evidence that board independence, women on the board, and frequency of board meetings do not have significant relationship with the environmental policy index of sustainability reporting of oil and gas companies in Nigeria (BDINP $=-0.073$, t-test $=-0.313, \mathrm{p}>0.05$; WMBD $=0.077$, $\mathrm{t}$-test $=0.212, \mathrm{p}>0.05$ and $\mathrm{FRBDM}=0.610$, $\mathrm{t}$ test $=1.041, \mathrm{p}>0.05)$. This also implies that board independence, women on the board and frequency of board meetings were not a significant factor influencing changes in the environmental policy index of sustainability reporting of oil and gas companies in Nigeria.

Concerning the magnitude of the estimated parameters for the coefficients of the regression analysis, a unit increase in the change in board size, women on the board, frequency of board meetings, and institutional holding will lead to $0.401,0.077,0.610$ and 0.766 increases in the environmental policy index of sustainability reporting of oil and gas companies in Nigeria respectively, while a unit increase in board independence will lead to a decrease of 0.073 in the environmental policy index of sustainability reporting of oil and gas companies in Nigeria. The Adjusted $\mathrm{R}^{2}$ measured the composition of corporate governance in environmental sustainability while the balance represents factors not considered in the model. In other words, it considered measured the proportion of the changes in the environmental policy index of sustainability reporting of oil and gas companies in Nigeria as a result of changes in the board independence, board size, frequency of board meetings, women on the board, institutional holding explains about 10 per cent changes in the environmental policy index of sustainability reporting of oil and gas companies in Nigeria, while the remaining 90 per cent 
were other factors explaining changes in the environmental policy index of sustainability reporting of oil and gas companies in Nigeria but where not captured in the model.

\subsubsection{Decision}

At $5 \%$ level of significance, the $F$ Test of 9.01 was statistically significant with $\mathrm{p}<0.05$ indicating that on the overall; the statistical significance of the model showed that the null hypothesis that corporate governance has no significant effect on environmental policy index of sustainability reporting in quoted oil and gas companies in Nigeria was rejected. Thus, the alternative hypothesis that corporate governance has significant effect on environmental policy index of sustainability reporting in quoted oil and gas companies in Nigeria was accepted.

\subsubsection{Discussion of Findings}

The study investigated the effect of corporate governance on environmental sustainability policy and the study found that corporate governance had a positive significant effect on environmental sustainability reporting in oil and gas companies quoted in Nigeria. This result was in tandem with the results of prior studies of (Amran\&Ooi, 2014; Manning, Braam\&Reinshach, 2018; Sanusi\&Sanusi, 2019; Oti, Mbu-Ogar, 2018; Eneh\&Amakor, 2019; Eze, Nweze\&Enekwe, 2016). For instance, Eneh and Amakor (2019) investigated the effect of firm attributes of firm size, leverage and profitability on sustainability reporting in Nigeria. The study then found that firm size had a positive significant effect on sustainability reporting while leverage and profitability exhibited negative significant effect on sustainability reporting.

Also, the study of Manning, Braam and Reimsbach (2018) examined the effects of board monitoring effectiveness and stakeholders' engagement on corporate sustainability performance and disclosure choices and found that in the short run, the companies monitoring effectiveness had a positive significant effect on sustainability reporting quality and sustainability reporting standards. Also that stakeholder's engagement had a positive effect on sustainability reporting quality and sustainability reporting standards both in the short and long run periods. On the contrary, the study results in this models seemed inconsistent with the results of the studies of (Juan, 2020; Amarjit\&Obradovich, 2015). Also, Juan (2020) found that a rapid evolution of the sustainability practice and reporting were negatively related with performance of the firms and were inadequate and the consequences of oil and gas sustainability program on the competitiveness were eminently unavoidable

\subsection{Hypothesis Two}

- $\quad$ Research Objective Two: investigate the moderating effect of firm size and firm leverage on the effect of corporate governance on environmental policy index of sustainability reporting in oil and companies quoted in Nigeria.

- Research Question Two: What was the moderating effect of firm size and firm leverage on the effect of corporate governance on environmental policy index of sustainability reporting in oil and gas companies quoted in Nigeria?

- Research Hypothesis Two $\left(\mathrm{H}_{02}\right)$ : There is no significant moderating effect of firm size and leverage on the effect of corporate governance on environmental policy index of sustainability reporting in oil and gas companies quoted in Nigeria.

\begin{tabular}{|c|c|c|c|c|}
\hline Variables & Coefficient & Cluster Standard Error & Z-test & Prob. \\
\hline Constant & -0.952 & 0.651 & -1.462 & 0.144 \\
\hline BDINDP & 0.205 & 0.254 & 0.807 & 0.420 \\
\hline BDSIZE & 0.196 & 0.341 & 0.575 & 0.565 \\
\hline WMBD & 0.108 & 0.249 & 0.434 & 0.664 \\
\hline FRBDM & $1.032^{* * *}$ & 0.399 & 2.586 & 0.005 \\
\hline INSH & 0.273 & 0.299 & 0.913 & 0.361 \\
\hline FRMSZ & 0.052 & 0.055 & 2.455 & 0.348 \\
\hline FRMLEV & $0.002^{* *}$ & 0.001 & 0.014 \\
\hline Adjusted R & 0.180 & & & \\
\hline Wald-Test & $32053.60(0.000)$ & & & \\
\hline Hausman Test & $1.65(0.478)$ & & & \\
\hline Bresuch-Pagan RE Test & $218.44(0.000)$ & & & \\
\hline Heteroscedasticity Test & $626.88(0.000)$ & & & \\
\hline Serial Correlation Test & $382.16(0.000)$ & & & \\
\hline Pesaran CSI & $-0.54(0.591)$ & & & \\
\hline Observations & 120 & & & \\
\hline
\end{tabular}

Table 2: Corporate Governance, Firm Size and Firm Leverage on Environmental Policy Index of Sustainability Reporting Dependent Variable: ENVPY

Source: Researcher's Computation (2021) 
Notes: Table 2 reports the cluster random effect model that corrects for autocorrelation and heteroscedasticitypanel regression results of the effects of corporate governance, firm size and leverage on environmental policy index of sustainability reporting of selected oil and gas companies Nigeria. The dependent variable was Environmental Policy Index of Sustainability Reporting (ENVPY). The independent variables were Board Independence (BDINDP), Board Size (BDSIZ), Institutional Holding (INSH), Women on Board (WMBD), and Frequency of Board Meeting (FRBDM). The moderating variables were Firm Size (FSIZ) and Firm Leverage (FLEV).

${ }^{*}$ Significant at $10 \%,{ }^{* *}$ Significant at $5 \%,{ }^{* * *}$ Significant at $1 \%$.

\subsubsection{Interpretation of Diagnostic Test}

From Table 4.2, the diagnostic test reported were the Hausman test, the Bresuch-Pagan RE Test for random effect test, the heteroskedasticity, the Wooldridge test for autocorrelation and the Pesaran's test of cross-sectional independence, these tests were carried out so as to determine the appropriateness of the estimation technique for the specified model. First, the Hausman test was used to determine the appropriateness between the fixed effect and the random effect model. The null hypothesis of the Hausman specification test was that there was no correlation between the random effect and fixed effect model, thus the random effect estimates were efficient and consistent, and that the fixed effect estimates were inefficient and the alternative hypothesis that the fixed effect model was consistent and efficient. The Hausman statistic of 1.65 with a probability value of 0.478 was greater than the $5 \%$ level of significance hence, the nonrejection of the null hypothesis and the rejection of the alternative hypothesis. This implies that the random effect model was efficient and appropriate. To determine the appropriateness of the random effect model, the Bresuch-Pagan RE Test for random effect model was conducted; the result showed that the statistic of 218.44 with a probability value of 0.000 was less than the $5 \%$ level of significance. Thus, the random effect model was appropriate.

To determine the cross-sectional dependence between the selected oil and gas companies in Nigeria, the Pesaran CD test was used. The statistic of -0.540 and with a probability value of 0.591 was not was statistically significant at $5 \%$ level of significance. This implies that the selected oil and gas companies were cross sectional independence. The BreuschPagan/Cook-Weisberg test for heteroscedasticity was carried out to determine if the variance of the residual was constant. The null hypothesis of homoscedasticity was rejected and the alternative hypothesis of heteroscedasticity was accepted. This was because the test statistic of 626.88 was statistically significant at 1 per cent level.

In testing for autocorrelation in the panel data, the Wooldridge test was used. The null hypothesis that the successive error terms were not correlated was rejected in favour of the alternative hypothesis that the successive error terms were serial correlated because the statistic of 382.16 with a probability value of 0.000 which was less than the $5 \%$ level of significance. However, with the presence of autocorrelation and heteroscedasticity, the study used the cluster option for the random effect model.

Model 2:

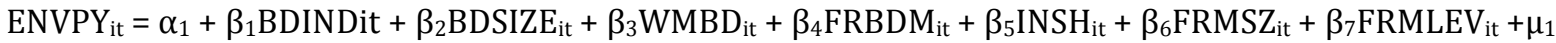

$\mathrm{ENVPY}_{\mathrm{it}}=-0.952+0.205 \mathrm{BDINDit}+0.196 \mathrm{BDSIZE}_{\mathrm{it}}+0.108 \mathrm{WMBD}_{\mathrm{it}}+1.032 \mathrm{FRBDM}_{\mathrm{it}}+0.273 \mathrm{INSH}_{\mathrm{it}}+0.052 \mathrm{FRMSZ}_{\mathrm{it}}+$ 0.002 FRMLEV $_{\text {it }}$
T-test
$-1.462$
0.807
0.565
0.434
2.586
0.913
0.939
2.455

\subsubsection{Interpretation of Results}

Table 2showed the results of regression analysis of the effects of corporate governance, firm size and firm leverage on environmental policy index of sustainability reporting of oil and gas companies in Nigeria. The results show that board independence, board size, women on the board, frequency of board meetings, institutional holding, firm size and firm leverage have positive relationship with environmental policy index of sustainability reporting of oil and gas companies in Nigeria.

In addition, there was evidence that frequency of board meeting and firm leverage have significant relationship with the environmental policy index of sustainability reporting of oil and gas companies in Nigeria $(F R B D M=1.032$, t-test= 2.586, $\mathrm{p}<0.05$ and FRMLEV $=0.002$, t-test= 2.455, $\mathrm{p}<0.05)$, respectively. This implies that frequency of board meeting and firm leverage were significant factors influencing changes in the environmental policy index of sustainability reporting of oil and gas companies in Nigeria.

Conversely, there was evidence that board independence, board size, women on the board, institutional holding, and firm size do not have significant relationship with the environmental policy index of sustainability reporting of oil and gas companies in Nigeria (BDINP=0.205, t-test $=0.807, \mathrm{p}>0.05$; BDSIZE $=0.196$, $\mathrm{t}$-test $=0.575, \mathrm{p}>0.05 ; \mathrm{WMBD}=0.108, \mathrm{t}-$ test $=0.434, \mathrm{p}>0.05 ;$ INSH $=0.273$, t-test $=0.913, \mathrm{p}>0.05$ and FRMSZ $=0.052$, $\mathrm{t}$-test $=0.939, \mathrm{p}>0.05$ ). This also implies that board independence, board size, women on the board, institutional holding, and firm size were not a significant factor influencing changes in the environmental policy index of sustainability reporting of oil and gas companies in Nigeria.

Concerning the magnitude of the estimated parameters for the coefficients of the regression analysis, a unit increase in the change in board independence, board size, women on the board, frequency of board meetings, institutional holding, firm size and firm leverage will lead to $0.205,0.196,0.108,1.032,0.273,0.052$ and 0.002 increases in the environmental policy index of sustainability reporting of oil and gas companies in Nigeria, respectively

Adjusted $\mathrm{R}^{2}$ measures the composition of corporate governance in environmental sustainability while the balance represents factors not considered in the model. In other words, it considered measured the proportion of the changes in the environmental policy index of sustainability reporting of oil and gas companies in Nigeria as a result of changes in the board independence, board size, frequency of board meetings, women on the board, institutional holding, firm size and firm leverage explains about 18 per cent changes in the environmental policy index of sustainability reporting of oil and 
gas companies in Nigeria, while the remaining 82 per cent were other factors explaining changes in the environmental policy index of sustainability reporting of oil and gas companies in Nigeria but where not captured in the model.

\subsubsection{Decision}

At $5 \%$ level of significance, the Wald-Test of 32053.60 was statistically significant with $p<0.05$ indicating that on the overall; the statistical significance of the model showed that the null hypothesis that corporate governance, firm size and firm leverage has no significant effect on environmental policy index of sustainability reporting in quoted oil and gas companies in Nigeria was rejected. Thus, the alternative hypothesis that corporate governance, firm size and firm leverage has significant effect on environmental policy index of sustainability reporting in quoted oil and gas companies in Nigeria was accepted.

\subsubsection{Discussion of Findings}

The study in this model, examined the moderating effect of firm size and firm leverage on the relationship between corporate governance and environmental sustainability policy. The study regression in this aspect revealed mixed results, however, the joint result showed that corporate governance with firm size and firm leverage had a positive significant effect on environmental sustainability reporting in oil and gas companies quoted in Nigeria. The result revealed that stronger effect as corporate governance with the moderating variables of firm size and firm average exhibited a positive significant effect on environmental sustainability policy. The report was consistent with the results of Odoemelam and Okafor (2018) who examined the effect of corporate governance on environmental disclosure of nonbanking firms listed in the Nigerian Stock Exchange, anchoring on the trinity theories of agency theory, stakeholder and legitimacy theory. The study also found that firm characteristics of firm size had a positive influence on environmental disclosure. However, the results were not in tandem with the results obtained by Jain and Winner (2016) investigated the corporate social responsibility and sustainability reporting practices in top sized companies in India and found that corporate governance, social responsibility and firm size had a negative significant effect on sustainability reporting among the companies investigated and such did not comply

\section{Conclusion and Recommendation}

This study investigated the effect of corporate governance on environmental policy index of sustainability reporting in oil and gas companies quoted in Nigeria. It equally examined the moderating effect of firm size and financial leverage on the environmental policy index of sustainability reporting in oil and gas industries in Nigeria. It was concluded that there is significant positive effect of corporate governance on environmental policy index of sustainability reporting in oil and gas companies quoted in Nigeria. It was also concluded that corporate governance with moderating effect of firm size and firm leverage had positive significant effect on the environmental policy index of sustainability reporting in oil and gas companies quoted in Nigeria.

The study thus recommends as follows:

Shareholders should obtain adequate information relating to environmental protection having present and potential litigation, contingent liabilities or fines to the companies they have invested in, as these will guide them in making useful investment decisions, planning and portfolio diversifications in the oil and gas companies in Nigeria.

Also, investors should demand from the management, annual environmental audits, external assurance, adequate budgeting and investment on pollution control, as well as consistent and robust environmental sustainability reporting disclosure that will keep them on-the-known about the state of their firms.

\section{References}

i. Adediran, S. A., \&Alade, S. O. (2013). The impact of environmental accounting on corporate performance. European Journal of Business and Management, 5(23), 141-151.

ii. Adeneye, Y. A., \& Ahmed, M. (2015). Corporate social responsibility and company performance. Journal of Business Studies Quarterly, 7(1), 151-166.

iii. Agyei-Mensah, G. (2016). Effect of firm-specific characteristics of debt equity ratio on voluntary disclosure level of rural banks in the Ashanti region of Ghana. Journal of Accounting and Finance, 32(2), 1-17.

iv. Akbas, H. E. (2016). The relationship between board characteristics and environmental disclosure: Evidence from Turkish listed banks. South East European Journal of Economics and Business, 11(2), 7-19.

v. Akinwunmi, A. J., Owolabi, A. S., \&Akintoye, I. R. (2018). Corporate board ethno - religious diversity and performance of quoted companies in Nigeria ICAN 2018 International Academic Conference proceedings. ( $4^{\text {th }}$ Ed). E-copy was available at http://www.icanig.org/ican/.Retrieved: 15 January 2020.

vi. Alhassan, A., \&Mansor, N. (2019). Sustainability disclosure on environmental reporting: A review of literature in developing countries.American Based Research Journal, 8(1), 1-13.

vii. Amarjit, G., \&Obradovich, J. D. (2015). The impact of corporate governance and financial leverage on the value of American Firms. International Research Journal of Finance and Economics, 9(1), 1-14.

viii. Ameer, R. \& Othman, R. (2012). Sustainability practices and corporate financial performance: A study based on the top global corporations. Journal of Business Ethics, 108(1), 61-79.

ix. Amran, A., \&Ooi, S. K. (2014). Sustainability reporting: meeting stakeholder demands. Strategic Direction, 30(7), $38-41$.

x. Asuquo, I. A., Dada, E. T., \&Onyeogaziri, U. R. (2018). Performance of economic disclosure in Nigeria. International Journal of Business \& Law Research, 6(3), 1-10. 
xi. Bennett, M., Schaltegger, S., \&Zvezdov, D. (2017). Exploring corporate practices in management accounting for sustainability; ICAEW: London, UK, 1-48.

xii. Birindelli, G., Dell'Atti, S., \&Iannuzzi, A. P. (2018). Composition and activity of the board of directors: Impact of environmental, social and government performance. Sustainability, 10(10), 1-20

xiii. Budiharta, P., \&Kacaribu, H. E. P. B. (2020). The influence of board of directors, managerial ownership, and audit committee on carbon emission disclosure: A study of non-financial companies listed on BEI. RIBER, 9(5), 75-87.

xiv. Burhan, A. H. N., \&Rahmanti, W. (2012). The impact of sustainability reporting on company performance. Journal of Economics, Business, and Accountancy Ventura, 15(2), 257-272.

$x v$. Butt, U. (2019). Profits, financial leverage and corporate governance. International Journal of Managerial Finance, 16(2), 203-223.

xvi. Cardoni, A., Evgeniia, K., \& Simone Terzani, S. (2019). Evaluating the intra-industry comparability of sustainability reports: the case of the oil and gas industry. Sustainability, 12(5), 1-28.

xvii. Cupertino, S., Consolandi, C., \& Vercelli, A. (2019). Corporate social performance, financialization, and real investment in US manufacturing firms. Sustainability, 11(3), 1-20.

xviii. Edike, S., \&Otuya, S. (2018). Effect of social responsibility reporting on corporate performance in Nigeria. The Nigerian Accountant: Journal of the Institute of Chartered Accountants of Nigeria, 51(2), 10-46.

xix. Efale, L. M. \&Otuya, S. (2018) Environmental responsibility reporting and financial performance of quoted oil \& gas companies in Nigeria. European Journal of Business and Innovation Research, 6(6), 23-34.

xx. Egbunike, A. P., \&Tarilaye, N. (2017). Firm specific attributes and voluntary environmental disclosure in Nigeria: Evidence from listed manufacturing companies. Academy of Accounting and Financial Studies Journal, 21(3), 1-9.

xxi. Ehimare, O. A., Taiwo, N. J., \&Okorie, U. (2013). The role of corporate governance in the growth of Nigerian banks. Journal of Business Law and Ethics, 1(1), 44-56.

xxii. Eneh, O., \&Amakor, I. C. (2019). Firm attributes and sustainability reporting in Nigeria. International Journal of Academic Accounting, Finance \& Management Research, 3(6), 36-44.

xxiii. Ezeagba, C. E., John-Akamelu, C. R., \&Umeoduagu, C. (2017). Environmental accounting disclosures and financial performance: A study of selected food and beverage companies in Nigeria (2006-2015). International Journal of Academic Research in Business and Social Sciences, 7(9), 162-174.

xxiv. Eze, J. C., Nweze, A. U. \&Enekwe, C. I. (2016). The effects of environmental accounting on a developing nation: Nigerian experience. European Journal of Accounting, Auditing and Finance Research, 4(1), 17-27.

xxv. Ghani, E. K., Jamal, J., Puspitasari, E., \&Gunardi, A. (2018). Factors influencing integrated reporting practices among Malaysian public listed real property companies: a sustainable development effort. International Journal of Managerial and Financial Accounting, 10(2), 144-162.

xxvi. Gholami, R., Sulaiman, A. B., Ramayah, T., \&Molla, A. (2013). Senior managers' perception on green information systems (WAS) adoption and environmental performance: Results from a field survey. Information and Management, 50(7), 431-438.

xxvii. Grigorescu, A., Maer-Matei, M. M., Mocanu, C., \&Zamfir, A. M. (2020). Key drivers and skills needed for innovative companies focused on sustainability. Sustainability, 12(7), 1-20.

xxviii. Gul, S., Muhammad, F., \& Rashid, A. (2017). Corporate governance and corporate social responsibility: The case of small, medium, and large firms. Pakistan Journal of. Commerce, and Social Science, 11(2), 1-34.

xxix. Haladu, A. (2016). Arguments for adopting only environmentally sensitive firms in assessing environmental information disclosures. International Journal of Management Research \& Review, 6(9), 1204-1212.

xxx. He, P., Shen, H., Zhang, Y., \& Ren, J. (2019). External pressure, corporate governance, and voluntary carbon disclosure: Evidence from China. Sustainability, 11(3), 1-24.

xxxi. Henri, J. F., \&Journeault, M. (2010). Eco-control: The influence of management control systems on environmental and economic performance. Accounting, Organizations and Society, 35(1), 63-80.

xxxii. Hussain, H. I., Slusarczyk, B., Kamarudin, F., Thaker, H. M. T., \&Szczepa, W., K. (2020). An investigation of an adaptive neuro-fuzzy inference system to predict the relationship among energy intensity, globalization, and financial development in major ASEAN economies. Energies 2020, 13(5),850-862.

xxxiii. Hu, W., Du, J., \& Zhang, W. (2020). Corporate social responsibility information disclosure and innovation sustainability: Evidence from China. Sustainability, 12(6), 1-24.

xxxiv. Jain, R., \& Winner, L. H. (2016). CSR and sustainability reporting practices of top companies in India. Corporate Communications: An International Journal, 21(1), 36-55.

xxxv. Juan, J. N. (2020). A systematic review of sustainable banking through a co-word analysis. Sustainability, 12(1), $1-23$.

xxxvi. Laskar, N., Chakraborty, T. K., \&Maji, S. G. (2017). Corporate Sustainability Performance and Financial Performance: Empirical Evidence from Japan and India. Management and Labour Studies Sage Journal Publications, 42(2), 412-432.

xxxvii. Mahmood, Z., Kouser, R., Ali, W., Ahmad, Z., \& Salman, T. (2018). Does corporate governance affect sustainability disclosure? A mixed methods study. Sustainability, 10(10), 1-20.

xxxviii. Marimuthu, T. (2008). Ethnic diversity at the executive level of the management on firm financial performance in Malaysia. International Journal of Business Studies, 6(1), 234-251. 
xxxix. Manning, B., Braam, G., \&Reimsbach, D. (2018). Corporate governance and sustainable business conductEffects of board monitoring effectiveness and stakeholder engagement on corporate sustainability performance and disclosure choices. Corporate Social Responsibility and Environmental Management, 25(2), 1021-1035.

xl. Meca, E. G., \& Palacio, J., C. (2018). Board composition and firm reputation: The role of business experts, support specialists and community influential. Business Research Quarterly. Available at: www.elsevier.es/brq: Retrieved: $12^{\text {th }}$ August 2020.

xli. Mulyanto, M., Awatara, I. G. P. D., \&Gunardi, A. (2018). Enhancing competence, environmental management system, job satisfaction and employee performance. Journal of Environmental Management and Tourism, 9(1), 40-45.

xlii. Munteanu, I., Grigorescu, A., Condrea, E., \&Pelinescu, E. (2020). Convergent insights for sustainable development and ethical cohesion: An empirical study on corporate governance in Romanian public entities. Sustainability, 12(1), 1-18.

xliii. Nasir, A. K., Kashan, M. K., Maleki, A., Jafari, N., Hashemi, H. (2020). Assessment of barriers to renewable energy development using stakeholders approach. Entrepreneurial Sustainability Issues, 7(2), 2526-2541.

xliv. Nosratabadi, S., Pinter, G., Mosavi, A., \&Semperger, S. (2020). Sustainable banking; Evaluation of the European business models. Sustainability, 12(2), 2314.

xlv. Nwaiwu, N. J. \&Oluka, N. O. (2018). Environmental cost disclosure and financial performance of oil and gas in Nigeria. International Journal of Advanced Academic Research, 4(2), 1-23.

xlvi. Nwobu, O. A. (2017). Determinants of corporate sustainability reporting in selected companies in Nigeria. Unpublished thesis submitted to the Department of Accounting, College of Business and Social Science, Covenant University, Ota, Ogun State, Nigeria.

xlvii. Nwobu, O. (2015). Relationship between corporate sustainability reporting and profitability and shareholders fund in Nigerian Banks. Journal of Accounting and Management, 5(3), 1-13

xlviii. Obeitoh, O., Ridzwana, B. M. S., \& Zaidi, B. M. D. (2017). Determinants and level of corporate sustainability disclosure on employees in Malaysia. InternationalJournal of Economic, Commerce and Management, 5(12), 218235.

xlix. Odoemelam, N., \& Okafor, R. G. (2018). The influence of corporate governance on environmental disclosure of listed non-financial firms in Nigeria. Indonesian Journal of Sustainability Accounting and Management, 2018, 2(1), 25-50.

l. Oncioiu, I., Petrescu, A., Bilcan, F. R., Petrescu, M, Delia-Mioara, P., \&Anghel, E. (2020). Corporate sustainability reporting and financial performance. Sustainability, 12(1), 1-13

li. Ong, T. S., Tho, H. S., Goh, H. H., Thai, S. B., \&Teh, B. H. (2016). The relationship between environmental disclosures and financial performance of public listed banks in Malaysia. International Business Management, 10(4), 461-467.

lii. Onyali, C. I., Okafor, T. G., \&Onodi, B. (2015). Effectiveness of triple bottom line disclosure practice in Nigeria: Stakeholders perspective. European Journal of Accounting Auditing andFinance Research, 3(3), 45-61.

liii. Osemene, F. O., Kolawole, D., \&Oyelakun, O. (2016). Effects of environmental accounting practices and sustainable development on the performance of Nigerian listed manufacturing. Journal of Clean Environmental, $8(2), 128-143$

liv. Oti, P. A., \&Mbu-Ogar, G. B. (2018). Analysis of environmental and social disclosure and financial performance of selected oil and gas quoted in Nigeria (2012-2016). Journal of Accounting and FinancialManagement, 4(2), 1-12.

lv. Otuya, S., Ofiemun, G., \&Akporien, F. (2019). Does financial statement information still matter? Research Journal of Finance and Accounting, 10(13), 16-22.

lvi. Ouvrard, S., Jasimuddin, S. M., \&Spiga, A. (2020). Does sustainability push to reshape business models? Evidence from the European wine industry. Sustainability,12(3), 25-36.

lvii. Owolabi, S. A., Adegbie, F. F., \&Oyetunji (2020). Effect of sustainability reporting on relevance of accounting information of deposit money banks and gas companies listed in Nigeria. The international journal of business \& management, $8(3), 1-23$.

Iviii. Oyewo, B. M., \&Badejo, S. O. (2014). Sustainable development in reporting practices by Nigerian banks. Mediterranean Journal of Social Sciences,5(23), 2535-2544.

lix. Perrault, E., \& Clark, C. (2016). Environmental shareholder activism: Considering status and reputation in firm responsiveness. Organization \& Environment, 29(2), 194-211.

lx. Sabishchenko, O. Rebilas, R., Sczygiol, N., \&Urbanski, M. (2020). Ukraine energy sector management using hybrid renewable energy systems. Energies, 13(5), 1-17.

lxi. Saman, U. P. (2019). Environmental accounting and financial performance of oil and gas companies in Nigeria. Research Journal of Finance and Accounting, 10(10), 192-202

lxii. Sanusi, K. A., \&Sanusi, O. O. (2019). Environmental sustainability reporting practices in Nigeria: Were clouds darker or fairer in the manufacturing industry? International Journal of Social Sciences and Humanity Studies, 2(2), 39-60.

lxiii. Saona, P., Muro, L., Martin, P. S., \&Baier-Fuentes, H. (2019). Board of Director's gender diversity and its impact on earnings management: an empirical analysis for select European firms Technological and Economic Development of Economy, 25(4), 634-663.

lxiv. Sulkowski, A. J., Edwards, M., \& Freeman, R. E. (2017). Shake your stakeholder: Firms leading engagement to cocreate sustainable value. Organizational Environment, 25(4), 1-21. 
lxv. Susanto, A., \&Meiryani, M. (2019). The impact of environmental accounting information system alignment on firm performance and environmental performance: a case of small and medium enterprises $s$ of Indonesia. International Journal of Energy Economics and Policy, 9(2), 229-236.

lxvi. Umukoro, O. E., Uwuigbe, O. R., Uwuigbe, U., Adegboye, A., Ajetunmobi, O., \&Nwaze, C. (2019). Board Expertise and Sustainability Reporting in Listed Banks in Nigeria. Earth and Environmental Science, 2(3), 1-9.

lxvii. Weng, H. R., Chen, J., \& Chen, P. (2015). Effects of green innovation on environmental and corporate performance: A Stakeholder perspective, Sustainability, 7(7), 4997-5026.

lxviii. Xing, X., Liu, T., Wang, J., Shen, L., \& Zhu, Y. (2019). Environmental regulation, environmental commitment, sustainability exploration/exploitation innovation, and firm sustainable development. Sustainability, 11(12), 120.

lxix. Yang, T. K., \& Yan, M. R. (2020). The corporate shared value for sustainable development: An Ecosystem perspective. Sustainability, 1(2), 1-23. 